16. Chornovol I. P. Didushycjkyj Volodymyr // Encyklopedija istoriji Ukrajiny : u 10 t. / red. rada: V. A. Smolij (gholova) ta in. ; NAN istoriji Ukrajiny, In-t istoriji Ukrajiny. Kyjiv : Nauk. dumka, 2004. T 2. S. 400.

17. Brzek G. Muzeum im. Dzieduszyckich we Lwowie i jego tworca. Lublin : Lubelskie Nowe, 1994. $299 \mathrm{~s}$.

18. Dzieduszycki M. Kronika domowa Dzieduszyckich. Lwów : Drukarnia Zakładu narodowego im. Ossolińskich, 1865. $480 \mathrm{~s}$.

19. Dzieduszycki W. Przewodnik po muzeum im. Dzieduszyckich we Lwowie. Lwów, 1895. 35 s.

20. Kronika// Łowiec. 1881. № 7. S.112.

21. Szafer W. Pamiatka Pieniacka // Sylwan. 1912. № 30. S. 361-366.

22. Tyrowicz M. Dzieduszycki Włodzimierz (1825-1899) // Polski Słownik Biograficzny. Kraków : Polska Akademia Umiejętności, 1948. T. VI. S. 123-126.

Статтю надіслано до редколегії 28.04.2019 р. Статтю рекомендовано до друку 05.06.2019 р.

УДК:94(477) «18-19»

DOI: https://doi.org/10.31652/2411-2143-2019-29-14-19

\author{
Володимир Очеретяний \\ Вінницький навчально-науковий інститут економіки \\ Тернопільського національного економічного університету, \\ кандидат історичних наук, доцент (Україна) \\ Інна Ніколіна \\ Вінницький державний педагогічний університет імені Михайла Коцюбинського, \\ кандидат історичних наук, доцент (Україна)

\section{Міжнародно-інформаційна діяльність дипломатичної місії УНР у Празі 1921-1923 рр.}

\begin{abstract}
Анотація. Стаття $\epsilon$ продовженням дослідження міжнародно-інфоомаційної, видавничої та пропагандистської діяльності Української надзвичайної дипломатичної місії УНР у Чехословаччині протягом 1921-1923 років. У дослідженні приділена увага вивченню наявної інфоормаційної та видавничої роботи дипломатичної місії у Празі з початком екзильної діяльності Державного Центру УНР. У своїй роботі дипмісія в Празі намагалась привернути увагу європейських політичних кіл до долі України, ї законних державних прав і геополітичних інтересів. Ця стаття є спробою узагальнюючого підходу до дослідження історії міжнародної інфоормаційної діяльності Української надзвичайної дипломатичної місії у ЧСР.

Ключові слова: зовнішньополітична пропаганда, інфрормаційний вплив,
\end{abstract} антиукраӥнська пропаганда, пресове бюро, часопис, інфрормаційний відділ.

Після остаточної втрати території та державної незалежності України, розпочався еміграційний період життя та діяльності М. Славинського (1921-1945). Діяльність очолюваної ним дипломатичної місії була спрямована на інформування міжнародної спільноти про державотворчі процеси у зв'язку з утворенням Державного Центр УНР в екзилі.

Ціль нашої статті: проаналізувати публікації, що стосувалися міжнародно-інформаційної та видавничої діяльності Української надзвичайної дипломатичної місії (далі - УНДМ) у Празі впродовж 1921-1923 рр.

Наявний обсяг публікацій про видавничу та інформаційну діяльність УНДМ у ЧСР в період 1921-1923 рр. майже відсутній у вітчизняній історичній науці. Праці сучасних дослідників суспільно-політичної думки стосуються, насамперед, вивчення зовнішньополітичних зусиль певних фрорм національної державності [1]. Через висвітлення проблем української дипломатії у країнах Центральної та Східної Європи деякі дослідники у низці наукових й науково-популярних праць присвячують увагу цьому питанню $[2 ; 3 ; 4 ; 5 ; 6]$.

Після остаточної окупації більшовиками України в 1921 році М. Славинський продовжував працювати на посаді Голови УНДМ в ЧСР.

Про згадані події він свідчив на допитах у Лук'янівській в'язниці:“У кінці 1920 року, коли була проголошена Радянська Україна й уряд УНР відбув за кордон, до Польщі, я як представник цього уряду далі діяв у напрямі існування України незалежною державою аж до 1923 року, тобто доти, коли Україна ввійшла до складу Радянського Союзу" [7, арк. 94]. Про натяк слідчого який вів його справу, чому він не закрив дипмісію, коли була проголошена радянська влада на Україні, М. Славинський вказував: "Я гадав, що боротьба за самостійність існування України ще 
не припинилась, що УНР в той час мала свої війська й певну частину території, а тому й далі працював у місії" [7, арк. 94].

До важливих напрямків зовнішньо-політичного курсу УНР належала ефективна інформаційно-пропагандистська діяльність, адже європейські політичні кола i, особливо, громадськість переважним чином залишалися в інформаційному вакуумі про державотворчі домагання українського народу. Через це основним напрямом інформмаційної діяльності дипмісії були безпосередні контакти із європейськими $3 \mathrm{MI}$, що давало можливість для ознайомлення політичних та громадських кіл іноземних держав з зовнішньополітичним курсом уряду УНР та подіями в Україні.

Розуміючи цю важливу обставину в поінформованості європейської громадськості при УНДМ в Празі, продовжували свою роботу інформаційне та пресове бюро, в штатному складі 11 працівників [8, арк. 23].

Очолювана М. Славинським дипмісія проводила чималу інформаційно-політичну кампанію серед урядових кіл і громадськості ЧСР [9, с. 169]. Співробітництво із закордонними медіа втілювалося шляхом підготовки працівниками представництва публікацій та інформаційноаналітичних матеріалів, розповсюдження важливих прес-релізів та спеціальних інформаційних бюлетенів, "замовлення" просвітницьких матеріалів про Україну в іноземних публіцистів.

Досить актуальним залишалося завдання широкого розповсюдження серед зарубіжних офіційно-політичних кіл та громадськості інформації про діяльність уряду УНР в екзилі на міжнародній арені та опір в Україні більшовикам. У звіті МЗС УНР від липня 1920 р. наголошувалося: "Наша держава, для підтримки української державності взагалі і українського питання за кордоном має тільки два фактори: 1) армію, що зброєю в руках визначає перед світом існування України, і 2) пресу, завдяки якій можна впливати на хід політичних подій відносно України" [10, арк. 22].

Інформаційно-пропагандистські зусилля дипмісії в Празі особливо були затребувані в світлі протиставляння пропаганді зовнішніх ворогів за кордоном по відношенню до українського державотворення, найбільш ярими представниками якої були більшовицька Росія, маріонетковий український радянський уряд та російський шовіністичний “білий рух".

Висвітлення українського питання на свій лад було пріоритетним напрямком функціонування проросійських небільшовицьких політичних кіл, як на теренах колишньої імперії, так і в середовищі емігрантів.

Для запобігання антиукраїнській пропаганді та спростування неправдивих відомостей про діяльність УНР, дипмісія в ЧСР не лише оприлюднила в чеських ЗМІ ряд власних інформаційнопубліцистичних матеріалів про українську державність, але й налагодила співпрацю з автором низки праць про Україну чеським публіцистом Я. Нечасом [11, арк. 4].

Весною 1921 р. під час проведення міжнародного ярмарку промислових товарів у столиці ЧСР дипмісія УНР здійснила інформаційну кампанію серед усіх чеських та закордонних торговопромислових фрірм, випустивши 10000 інформаційних листівок чеською та есперантською мовами про Україну, зробивши наголос на значимості ї̈ окремих галузей виробництва для співпраці в економічній сфері з країнами Європи [11, арк. 39]. Про це у своєму листі до МЗС УНР у березні 1921 р. місія повідомляла: "Ця форма пропаганди, користується значною симпатією і звернула загальну увагу” [11, арк. 39]. У звітах дипмісії також наголошувалось: “... чимало чехів стали дивитися на українське життя українськими очима, тобто чесно і щиро почали підпирати наше праве діло, до якого ставилися негативно лише через те, що були або зовсім не ознайомлені, або ж перебували під впливом ворожої нам фральшованої інформації з боку Москви та Кракова чи Варшави" [11, арк. 12].

Значна робота інформаційного відділу дипмісії у Празі була проведена в плані підготовки до друку так званої “Синьо-жовтої книги”, цим самим було виконане одне з провідних положень статуту Міністерства преси і пропаганди про інформування світової спільноти про Україну [12, арк. 290].

На початку 1921 р. дипмісією у ЧСР було укладено договір з видавництвом у Празі “Народня Політика" про друк “Синьо-Жовтої книги” тиражем 5000 примірників французькою і 2000 примірників українською мовами $[13$, арк. 6]. Для фрінансового забезпечення цього проекту РНМ Директорії ухвалила бюджет в 50 тис. чеських крон [13, арк. 9]. Відповідне фінансування уряд УНР здійснив для друку книги “Чехи про Україну" в кількості 5000 примірників [13, арк. 10].

Інформування європейських держав про визвольну боротьбу з більшовизмом стало пріоритетним завданням празької дипмісії під час другого Зимового походу армії УНР восени 1921 р., здійснюваного генералом-хорунжим Ю. Тютюнником. Дипмісії в чСР перед початком наступу українських збройних фрормувань на територію більшовицької України МЗС УНР поставило завдання: "У всякому разі за кордоном треба провести акцію в слідуючих напрямках:1) Вияснити закордонним політичним чинникам, що український народ цим новим повстанням - ще раз доказує світові, що він бореться за свою суверенність проти насилля 
червоних окупантів і що він $є$ вже цілком зрілим і одмінним од Російської нації. ... 5) Особливо треба підкреслювати всюди, в офріційних заявах і в відповідних повідомленнях до преси, про те, що весь провід повстання находитья в руках Головного Повстанчого Командування, яке провадить це повстаннє по плянові і дальшим вказівкам військового Командування і Уряду УНР" [14, арк. 2-2 зв.].

До першочергових завдань зовнішньополітичної пропаганди дипмісії в чСР належали заходи інформування зарубіжних політичних кіл та громадськості про позицію України в міжнародних відносинах, її державотворчі процеси, соціально-економічний та духовнокультурний розвиток, національна історія, а також інформаційна підтримка українців в діаспорі.

Суттєву допомогу в проведенні інформаційних заходів в центрально європейських державах дипмісія ЧСР надавала різними галузевими міністерствами УНР та виконувала окремі їх доручення. Так, для Міністерства ісповідань УНР було підготовлено аналіз стосовно релігійної ситуації у ЧСР. У своєму листі на весні 1921 р. дипмісія повідомляла: "В даний момент чеський церковно-релігійний рух переживає кризу з причин очевидних тенденцій серед частини прихильників нової національної чеської церкви до злиття зі сербською православною церквою. В зв'язку з тим був у Празі недавно сербський єпископ Доситей. Під час його побуту дійшло неначе до якогось об'єднання, яке однак потім було демонтоване більшістю визнавачів нової чеської релігії” [15, арк. 32]. У листуванні до голови місії у Празі від 26 травня 1921 р. вказувалося: “... на Україні відбувається великий церковний рух в напрямку створення національної української церкви. I в найблищому часі потрібним стане велике число добре освічених пан-отців для праці як в самій церкві так і на посадах церковних і міністерстві Ісповідань" [16, арк. 22-23]. Саме тому міністерство звернулось з проханням до місії висвітлити в чеських $3 \mathrm{Ml}$ зазначену вище проблему та звернутись до вищих релігійних навчальних закладів 3 пропозицією навчання українських студентів-теологів [16, арк. 23].

Українська дипломатія не втрачала можливості заявити про Україну беручи участь у міжнародних науково-культурних форумах, що відбувалися в ЧСР. Улітку 1921 р. на запрошення чеського уряду українська делегація відвідала XIII Міжнародний конгрес есперантистів у Празі. На ньому було представлено 45 держав світу з чисельністю 2500 делегатів.

Представник місії УНР у своєму зверненні до учасників конгресу повідомив про можливу згоду Міністерства освіти УНР включити мову есперанто як фракультативний предмет програми для вивчення у школах [15, арк. 50]. У листуванні з Праги до МЗС УНР від серпня 1921 р. наголошувалось: "Свій локаль для конференції есперантських представників від малих і поневолених держав і що відбулась 2 серпня у двох засіданнях вранці і ввечері. Були на ній представники Ірландці, (крім Англії), Шотландці, литовці, Фламандці, валони, Чехи, Українці, Жиди, Бельгійці, і напів-офіціально німець” [15, арк. 50]. За подання української сторони обговорювалося питання "організації інформаційної централі на есперантській мові для поінформування цілого світу про положення малих і поневолених народів, видання спеціального збірника" [15, арк. 51].

Досить вдалими для інформаційної роботи дипмісії були особисті знайомства М. Славинського, що спробував привернути увагу до "української проблеми" використовуючи XII світовий Конґрес сіоністів, який проходив у вересні 1921 р. у Карлсбаді. У своєму звіті про співпрацю з єврейськими лідерами Конгресу до уряду УНР восени 1921 р., М. Славинський писав: "Серед сіоністичних лідерів був відомий у нас діяч В.Е. Жаботинський тепер член Центрального Виконавчого Сіоністичного Комітета і шеф їхньої інформаційної служби (під їх впливом 450 щоденних ґазет у цілому світі), з яким я мав два побачення. Як старі приятелі ми обговорювали принципіяльно справу, як налагодити попсовану жидівську світову опінію щодо Українства. Я дав йому весь матеріял який мав, а крім того ми напали на думку про заснування жидівської жандармерії” [17, с. 114].

За задумом Державного Центру УНР в екзилі українські збройні сили мали розпочати військові дії проти більшовицької України і тому близько 15-тисяч їі вояків перебували на кордоні з УСРР. Похід на територію радянської України планувався на весну 1922 року. Побоювання, що з початком військової кампанії можуть спалахнути погроми, В. Жаботинський запропонував М. Славинському створити єврейські жандармські підрозділи у вигляді гарнізонів у невеликих містах України. Після попередніх переговорів на початку вересня 1921 року в Карлсбаді було підписано договір між В. Жаботинським і М. Славинським. У ньому вказувалось: “ ... створення автономної жидівської жандармерії в період перехідного часу для захисту своїх інтересів для недопущення насильств між християнським і жидівським населенням щоб виключити можливі єврейські погроми" [18, арк. 190 зв.]. Хоча, укладений договір не мав жодних практичних наслідків для обох сторін, він привернув увагу не лише євреїв, а й світової спільноти до проблеми єврейських погромів в Україні, в організації яких звинувачували Головного Отамана УНР С. Петлюру. Захищаючи його від подібних провокативних звинувачень, М. Славинський звітував перед урядом УНР: “Моє привітання і наші конфреренції уже самі собою мали цей 
добрий наслідок, що спинили одну неприємну для У.Н. Р. акцію, а іменно, - велика ґрупа східньоевропейських і анґлійсько-американських сіоністів хотіла при обговоренню питання про погроми на Україні виставити військо і уряд У.Н.Р. виновниками цих подій, покликаючись головним чином на інформації з "Українського Прапору" і инших галицьких видань - бо, як вони говорили, то самі українці про себе пишуть. Акція цеї ґрупи була погашена моїми і Жаботинського інформаціями і поясненнями" [17, с. 114-115].

Підсумовуючи, варто зазначити, що інформаційно-пропагандистська робота дипмісії у Празі майже не вплинула на зовнішньополітичну позицію урядових кіл ЧСР та інших держав центральної Європи, які суттєво залежали від політики західних держав та США та не могли допомогти Україні в боротьбі більшовизмом за її незалежність.

\section{ДЖЕРЕЛА ТА ЛІТЕРАТУРА:}

1. Будков Д. В. Організація зовнішньополітичного інформування за доби Директорії Української Народної Республіки // Міжнародні зв'язки України: наукові пошуки і знахідки. Київ, 1993. Вип. 4. С. $12-20$.

2. Будков Д. В. 3 історії міжнародно-інформаційної діяльності Державного центру УНР в екзилі // Вісник Київського інституту “Слов'янський університет”. Серія “Історія". 2000. Вип. 7. С. 10 19.

3. Віднянський С.В. Політика чехословацького уряду, щодо української еміграції в міжвоєнний період. // Міжнародні зв'язки України: наукові пошуки і знахідки. К., 1993. Вип. 3. С. 36-56.

4. Осташко Т. Дипломатичні представництва УНР у країнах Західної Європи (1918-1921рр.) / Т. Осташко, В. Соловйова // Проблеми вивчення історії української революції 1917-1921рр. Київ, 2002. С. 187-231.

5. Осташко Т. Матеріали нарад голів дипломатичних місій УНР за кордоном як джерело дослідження доби Директорії / Т. Осташко, В. Соловйова // Архіви України. 2003. № 4/6. С. 88-98.

6. Попенко Я.В. Румунська дипломатія в боротьбі за Бессарабію на Паризькій мирній конфреренції (січень-серпень 1919 р.). // Русин. 2018. № 53. URL: http://vital.lib.tsu.ru/vital/access/services/Download/vtls:000644055/ SOURCE1 (дата звернення: 26.12.2018).

7. ГДА СБ України. (Галузевий державний архів Служби Безпеки України). Спр. 71178. фрп. Слідча справа по звинуваченню Славінського М.А. 146 арк.

8. ЦДАВО України. Ф. 3696. Оп. 2. Спр. 396. 23 арк.

9. Політична історія України. XX століття: у 6 т. / [голов. редкол.: Курас Ф. (голова) та ін.]. К. : Генеза, 2002- . Т.5: Українці за межами УРСР (1918-1940). Керівник тому В. П. Трощанський. 2002. $720 \mathrm{c}$.

10. ЦДАВО України. Ф. 3696. Оп. 2. Спр. 14. 167 арк.

11. ЦДАВО України. Ф. 3696. Оп. 2. Спр. 576. 42 арк.

12. ЦДАВО України. Ф. 1429. Оп. 2. Спр. 18. 545 арк.

13. ЦДАВО України. Ф. 3696. Оп. 2. Спр. 271. 73 арк.

14. ЦДАВО України. Ф. 3519. Оп. 2. Спр. 3. 10 арк.

15. ЦДАВО України. Ф. 3696. Оп. 2. Спр. 73.71 арк.

16. ЦДАВО України. Ф. 3519. Оп. 1. Спр. 8. 46 арк.

17. Фельдман А. Угода Жаботинський - Славинський // Сучасність. 1976. Ч. 10. С. 109-116.

18. ЦДАВО України. Ф. 1429. Оп. 2. Спр. 91. 215 арк.

\section{REFERENCES:}

1. Budkov D. V. Orghanizacija zovnishnjopolitychnogho informuvannja za doby Dyrektoriji Ukrajinsjkoji Narodnoji Respubliky // Mizhnarodni zv'jazky Ukrajiny: naukovi poshuky i znakhidky. Kyjiv, 1993. Vyp. 4. S. 12-20.

2. Budkov D. V. Z istoriji mizhnarodno-informacijnoji dijaljnosti Derzhavnogho centru UNR v ekzyli // Visnyk Kyjivsjkogho instytutu "Slov'jansjkyj universytet". Serija "Istorija". 2000. Vyp. 7. S. 10 -19.

3. Vidnjansjkyj S.V. Polityka chekhoslovacjkogho urjadu, shhodo ukrajinsjkoji emighraciji v mizhvojennyj period // Mizhnarodni zv'jazky Ukrajiny: naukovi poshuky i znakhidky. K., 1993. Vyp. 3. S. 36-56.

4. Ostashko T. Dyplomatychni predstavnyctva UNR u krajinakh Zakhidnoji Jevropy (1918-1921 rr.) / T.Ostashko, V. Solovjova // Problemy vyvchennja istoriji ukrajinsjkoji revoljuciji 1917-1921 rr. Kyjiv, 2002. S. 187-231.

5. Ostashko T. Materialy narad gholiv dyplomatychnykh misij UNR za kordonom jak dzherelo doslidzhennja doby Dyrektoriji / T. Ostashko, V. Solovjova // Arkhivy Ukrajiny. 2003. № 4/6. S. 8898.

6. Popenko Ja.V. Rumunsjka dyplomatija v borotjbi za Bessarabiju na Paryzjkij myrnij konferenciji 
(sichenj-serpenj 1919 r.) // Rusyn. 2018. № 53. URL: http://vital.lib.tsu.ru/vital/access /services/Download/vtls:000644055/ SOURCE1 (data zvernennja: 26.12.2018).

7. GhDA SB Ukrajiny. (Ghaluzevyj derzhavnyj arkhiv Sluzhby Bezpeky Ukrajiny). Spr. 71178. fp. Slidcha sprava po zvynuvachennju Slavinsjkogho M.A. 146 ark.

8. CDAVO Ukrajiny. F. 3696. Op. 2. Spr. 396. 23 ark.

9. Politychna istorija Ukrajiny. XX stolittja: u 6 t. / [gholov. redkol.: Kuras F. (gholova) ta in.]. K. : Gheneza, 2002. T.5: Ukrajinci za mezhamy URSR (1918-1940). Kerivnyk tomu V. P. Troshhansjkyj. 2002. $720 \mathrm{~s}$.

10. CDAVO Ukrajiny. F. 3696. Op. 2. Spr. 14. 167 ark.

11. CDAVO Ukrajiny. F. 3696. Op. 2. Spr. 576. 42 ark.

12. CDAVO Ukrajiny. F. 1429. Op. 2. Spr. 18. 545 ark.

13. CDAVO Ukrajiny. F. 3696. Op. 2. Spr. 271. 73 ark.

14. CDAVO Ukrajiny. F. 3519. Op. 2. Spr. 3. 10 ark.

15. CDAVO Ukrajiny. F. 3696. Op. 2. Spr. 73.71 ark.

16. CDAVO Ukrajiny. F. 3519. Op. 1. Spr. 8. 46 ark.

17. Feljdman A. Ughoda Zhabotynsjkyj - Slavynsjkyj // Suchasnistj. 1976. Ch. 10. S. 109-116.

18. CDAVO Ukrajiny. F. 1429. Op. 2. Spr. 91. 215 ark.

\author{
Владимир Очеретяный \\ Винницкий учебно-научный институт экономики \\ Тернопольского национального экономического университета, \\ кандидат исторических наук, доцент (Украина) \\ Инна Николина
}

Винницкий государственный педагогический университет имени Михаила Коцюбинского, кандидат исторических наук, доцент (Украина)

\begin{abstract}
Аннотация. Данная статья является продолжением исследования международноинформационной, издательской и пропагандистской деятельности Украинской чрезвычайной дипломатической миссии УНР в Чехословакии в течение 1921-1923 годов. В исследовании уделено внимание изучению имеющейся информационной и издательской работы дипломатической миссии в Праге $c$ началом деятельности в изгнании Государственного Центра УНР. В своей работе дипмиссия в Праге пыталась привлечь внимание европейских политических кругов к судьбе Украины, ее законных государственных прав и геополитических интересов. Данная статья является попыткой обобщающего подхода к исследованию истории международной информационной деятельности Украинской чрезвычайной дипломатической миссии в ЧСР.
\end{abstract}

Ключевые слова: внешнеполитическая пропаганда, информационное воздействие, антиукраинская пропаганда, прессовое бюро, журнал, информационный отдел.

\author{
ABSTRACT \\ Volodymyr Ocheretianyi \\ Vinnytsia Institute of Economics Ternopil national economic University, \\ $\mathrm{PhD}$ (History), Associate Professor (Ukraine) \\ Inna Nikolina \\ Vinnitsa Mykhailo Kotsiubynskyi state pedagogical University, \\ PhD (History), Associate Professor (Ukraine)
}

\title{
International information activities of the diplomatic mission of the UNR in Prague 1921-1923.
}

The proposed article is a continuation of the study on the processes of international information, propaganda and publishing activities of The Ukrainian extraordinary diplomatic mission of the UNR in Czechoslovakia during 1921-1923. The following national and departmental normative legal documents defining the direction of the international information work of the diplomatic mission and the specific tasks of the Ukrainian diplomatic missions with the formation and activities of the state center of the UNR in exile are highlighted.

In the study, much attention is paid to the study of the broad information and publishing work of the diplomatic mission in Prague, as a means of attracting the attention of European political circles and peoples to the fate of Ukraine, its legitimate state rights and geopolitical interests. The main publications in Czech and Ukrainian educational publications, which determined the direction and objectives for the dissemination abroad of information about the history and civilizational achievements of the Ukrainian people, its current state, the process of revival of national statehood, the desire of 
Ukraine in the international arena. The main bases of foreign policy propaganda, organizational structure and functions of the staff information Department of the diplomatic mission of the UNR in Czechoslovakia, assistance of public organizations and the Ukrainian Diaspora in the international information work of Ukrainian diplomats are considered. Information and cultural assistance to Ukrainians in the Diaspora and in the ethnic territories occupied by Bolshevik Russia is covered. Forms and methods of international information work, objective difficulties on the way of distribution abroad of truthful data on the Ukrainian state are investigated.

This article is an attempt to generalize the approach to the study of the history of international information activities Of the Ukrainian emergency diplomatic mission in the Czechoslovak Republic.

Key words: foreign policy propaganda, information influence, anti-ukrainian propaganda, press bureau, magazine, information department.

Статтю надіслано до редколегії 03.05.2019 р. Статтю рекомендовано до друку 15.06.2019 р.

УДК 94(477):34«1941/1943»

DOI: https://doi.org/10.31652/2411-2143-2019-29-19-25

\author{
Аліна Іваненко \\ Державний вищий навчальний заклад «Переяслав-Хмельницький державний педагогічний \\ університет імені Григорія Сковороди», \\ кандидат історичних наук, докторант (Україна)
}

\title{
Функціонування місцевих юридичних установ у зоні відповідальності Військової адміністрації окупованої України (1941 - 1943 рр.)
}

Анотація. У статті вказано, що для забезпечення населення юридичною допомогою шляхом надання порад, складання різних видів договорів, статутів тощо при Міській управі під загальним контролем Адміністративного відділу управи діяла Юридична консультація. Історіографрічний аналіз дав підстави для висновку, що на сьогодні досліджені лише окремі аспекти фоннкціонування місцевих юридичних установ, які діяли в областях Райхскомісаріату "Україна». Діяльність зазначених суспільних інституцій у зоні відповідальності Військової адміністрації окупованої України наразі перебуває поза увагою дослідників.

У статті з'ясовано, що Юридична консультація поєднувала в собі фуункції власне консультації та юридичного бюро; виявлено, що працівниками установи були кваліфріковані фрахівці, які мали вищу освіту, вони надавали усні консультації, допомагали складати скарги, договори та статути, представляли за потреби в суді. Доведено, що одним із шляхів встановлення правопорядку в окупованих Вермахтом регіонах України стало створення юридичних (правових) відділів при міських та районних управах, нотаріату, а також юридичних консультацій.

Ключові слова: юридична консультація, послуга, такса, завідувач, консультант.

Окупаційний режим, установлений на теренах України військами Німеччини та ії союзників, став тяжким випробуванням для нашого народу. Знелюднення захопленого територіального масиву, перетворення його на життєвий простір для «арійської раси» - такими були цілі теоретиків і безпосередніх практиків нацистської ідеології. Від зазначеної мети вони не збиралися відступати навіть напередодні повної військової катастрофи. Але в процесі освоєння захоплених територій України актуалізувалася потреба в суто юридичних засобах врегулювання питань життєдіяльності населення, функціонування органів місцевого управління та поліційних формувань. До цього додалася й необхідність визначення особистого (громадянського), цивільного, майнового, сімейного статусу особи. Тобто, як не дивно це звучить, але окупаційній адміністрації довелося створювати певну систему правовідносин, метою і завданнями якої не завжди було досягнення цілей і виконання завдань політики Третього Райху в Україні. Ці аспекти окупаційного режиму регулювалися кримінальним, трудовим та соціальним законодавством, позасудовими й репресивно-каральними засобами впливу на суспільство. В інших сферах окупантам таки довелося створювати певну видимість законності і правопорядку. Одним із засобів виконання цього завдання стало створення юридичних (правових) відділів при міських та районних управах, нотаріату, а також юридичних консультацій. Останні надавали правові послуги як населенню, так і органам місцевого управління, упорядковуючи тим самим суспільні відносини, які продовжували функціонувати навіть у соціумі окупаційного типу.

Метою цього дослідження $є$ висвітлення діяльності місцевих юридичних установ, зокрема Юридичної консультації, у зоні відповідальності військової окупації. 